\title{
Improving Student Learning Outcomes in Suggestion Sentence Material with Learning Video Media for Class III Semester I SD Negeri Luwunggede 04
}

\section{Laeli Musyarofah}

SD Negeri Luwunggede 04

laeli25081986@gmial.com

\section{Article History}

accepted 14/11/2020

\begin{abstract}
The purpose of this study was to improve student learning outcomes in Indonesian language subject matter in grade III elementary schools using instructional video media. The research conducted was a Classroom Action Research (CAR) in two cycles, with each cycle having one meeting. The stages of each cycle are planning, implementing, observing and reflecting. Data collection techniques are observation and tests. Based on the data analysis, it was found that the use of instructional video media in Indonesian language subject matter content in suggestion sentences could improve student learning outcomes as indicated by the level of learning completeness in the initial conditions $40 \%$ to $60 \%$ in cycle 1 , and increased to $90 \%$ in cycle II. The final conclusion from the implementation of this classroom action research is that the use of instructional video media is able to improve student learning outcomes on Indonesian language subject matter content in the suggestion sentence material at SD Negeri Luwunggede 04, Larangan District, Brebes Regency.
\end{abstract}

Keywords: Learning video media, learning outcomes, Indonesian Language

\begin{abstract}
Abstrak
Tujuan dari penelitian ini adalah untuk meningkatkan hasil belajar siswa pada muatan pelajaran Bahasa Indonesia di sekolah dasar kelas III dengan menggunakan media video pembelajaran. Penelitian yang dilakukan adalah Penelitian Tindakan Kelas (PTK) sebanyak dua siklus, dengan setiap siklusnya satu kali pertemuan. Tahapan setiap siklusnya adalah tahap perencanaan, pelaksanaan, observasi dan refleksi. Teknik pengumpulan data adalah observasi dan tes. Berdasarkan analisis data, diperoleh hasil bahwa penggunaan media video pembelajaran pada muatan pelajaran Bahasa Indonesia materi kalimat saran dapat meningkatkan hasil belajar siswa yang ditunjukkan dengan tingkat ketuntasan belajar pada kondisi awal $40 \%$ menjadi $60 \%$ pada siklus I, dan meningkat menjadi $90 \%$ pada siklus II. Kesimpulan akhir dari pelaksanaan penelitian tindakan kelas ini adalah penggunaan media video pembelajaran mampu meningkatkan hasil belajar siswa pada muatan pelajaran Bahasa Indonesia materi kalimat saran di SD Negeri Luwunggede 04 Kecamatan Larangan Kabupaten Brebes.
\end{abstract}

Kata kunci: Media video pembelajaran, hasil belajar, Bahasa Indonesia

Social, Humanities, and Education Studies (SHEs): Conference Series https://jurnal.uns.ac.id/shes

p-ISSN 2620-9284

e-ISSN 2620-9292 


\section{SHEs: Conference Series $x(x)(20 x x) 00-00$}

\section{PENDAHULUAN}

Dunia pendidikan selalu berkembang seiring dengan berkembangnya dunia. Begitu juga dengan sarana dan prasarana pendidikan semakin memadai dan semakin lengkap. Jika dulu sekolah-sekolah menggunakan sarana yang seadanya, sekarang sudah semakin lengkap. Sehingga pembelajaran dapat terlaksana dengan maksimal. Demikian juga media yang dipakai dalam proses belajar mengajar semakin kompleks.

Perkembangan teknologi pada akhirnya juga merambah kepada dunia pendidikan. Banyak sekolah yang sekarang memakai teknologi ini untuk memperlancar pembelajaran di sekolah. Teknologi dalam pembelajaran bisa menjadi sarana pembelajaran, metode/media sebagai sumber belajar bagi peserta didik. Sebagai sarana teknologi merupakan alat untuk memperlancar pembelajaran. Sebagai metode/media teknologi sebagai inovator agar pembelajaran menjadi lebih menarik. Sedangkan sebagai sumber belajar tekonologi sebagai salah satu penyedia informasi bagi peserta didik.

Media pembelajaran merupakan hal penting dalam pelaksanaan proses pembelajaran. Sebaik apapun rencana pengajaran yang dibuat, tetapi tanpa penggunaan media yang sesuai mengakibatkan kebosanan baik di pihak guru maupun pihak siswa. Banyak media pembelajaran yang dapat digunakan oleh guru, namun penerapan suatu media belum tentu cocok untuk setiap kelompok belajar dan waktu yang berbeda. Sebagai guru SD harus mampu menerapkan berbagai strategi demi tercapainya tujuan pembelajaran yang diampunya, hal ini dimaksudkan untuk membangkitkan semangat anak dalam belajar, termotivasi dan minat yang tinggi untuk belajar.

Oleh karena itu peneliti mencoba merumuskan Masalah sebagai berikut: "Bagaimana penggunaan media video pembelajaran dapat meningkatkan hasil belajar Bahasa Indonesia tentang kalimat saran pada siswa kelas III SD Negeri Luwunggede 04?"

Menurut Slameto (2008:7) "hasil belajar adalah sesuatu yang diperoleh dari suatu proses usaha setelah melakukan kegiatan belajar yang dapat diukur dengan menggunakan tes guna melihat kemajuan siswa". Lebih lanjut Slameto (2008:8) mengemukakan bahwa "hasil belajar diukur dengan rata-rata hasil tes yang diberikan dan tes hasil belajar itu sendiri adalah sekelompok pertanyaan atau tugas-tugas yang harus dijawab atau diselesaikan oleh siswa dengan tujuan mengukur kemajuan belajar siswa".

Untuk mengatasi kendala tersebut, maka penulis mencoba melakukan perbaikan pembelajaran menggunakan media video pembelajaran. Sebagai salah satu media, video pembelajaran merupakan salah satu tekonologi pembelajaran yang memiliki kelebihan yang cukup baik untuk pelaksanaan pembelajaran. Media video pembelajaran adalah media yang menyajikan audio dan visual yang berisi konsep, prinsip, prosedur, teori aplikasi pengetahuan untuk membantu pemahaman terhadap suatu materi pembelajaran (Cheppy Riyana : 2007). Menurut Kamus Besar Bahasa Indonesia, video merupakan rekaman gambar hidup atau program televisi untuk ditayangkan lewat pesawat televisi, atau dengan kata lain video merupakan tayangan gambar bergerak yang disertai dengan suara. Video sebenarnya berasal dari bahasa Latin, video-vidivisum yang artinya melihat (mempunyai daya penglihatan); dapat melihat. Media video merupakan salah satu jenis media audio visual. Media audio visual adalah media yang mengandalkan indera pendengaran dan indera penglihatan. Media audio visual merupakan salah satu media yang dapat digunakan dalam pembelajaran menyimak. Media ini dapat menambah minat siswa dalam belajar karena siswa dapat menyimak sekaligus melihat gambar. Azhar Arsyad (2011 : 49) menyatakan bahwa video merupakan gambar-gambar dalam frame, di mana frame demi frame diproyeksikan melalui lensa proyektor secara mekanis sehingga pada layar terlihat gambar hidup. Dari pengertian di atas dapat disimpulkan, bahwa video 
merupakan salah satu jenis media audio-visual yang apat menggambarkan suatu objek yang bergerak bersama-sama dengan suara alamiah atau suara yang sesuai. Dengan menggunakan media video ini diharapkan dapat mencapai tujuan yang diharapkan.

Berdasarkan uraian diatas penulis mencoba melakukan penelitian dengan judul peningkatan hasil belajar siswa materi kalimat saran dengan media video pembelajaran kelas III semester 1 SD Negeri Luwunggede 04 Kecamatan Larangan Kabupaten Brebes. Tujuan penelitian ini adalah Untuk meningkatkan hasil belajar siswa dengan penggunaan media video pembelajaran pada muatan pelajaran Bahasa Indonesia materi kalimat saran kelas III SD Negeri Luwunggede 04 Tahun 2020/2021.

\section{METODE}

Jenis penelitian ini adalah Penelitian Tindakan Kelas disingkat PTK atau Classroom Action Research adalah bentuk penelitian yang terjadi di dalam kelas berupa tindakan tertentu yang dilakukan untuk memperbaiki proses belajar mengajar guna meningkatkan hasil belajar yang lebih baik dari sebelumnya. Penelitian Tindakan Kelas (PTK) adalah penelitian yang dilakukan oleh guru di dalam kelasnya sendiri melalu refleksi diri, dengan tujuan untuk memperbaiki kinerjanya sebagai guru, sehingga proses pembelajaran dapat berjalan dengan baik dan hasil belajar siswa meningkat (Hamzah B. Uno dkk, 2011: 41)

Penelitian tindakan kelas dapat dipakai sebagai implementasi berbagai program yang ada di sekolah, dengan mengkaji berbagai indikator keberhasilan proses dan hasil pembelajaran yang terjadi pada siswa atau keberhasilan proses dan hasil implementasi berbagai program sekolah.

Penelitian ini dilaksanakan dalam dua siklus, setiap siklus terdiri dari tahap perencanaan, pelaksanaan, observasi dan refleksi. Subyek penelitian ini adalah siswa kelas III SD Negeri Luwunggede 04 Tahun Pelajaran 2020/2021 yang berjumlah 20 peserta didik. Data yang dianalisis berupa data kualitatif yaitu penggunaan media video pembelajaran dan data kuantitatif yaitu hasil belajar bahasa indonesia peserta didik. Teknik pengumpulan data menggunakan observasi dan tes. Analisis data meliputi reduksi data, penyajian data, dan penarikan kesimpulan. Untuk Hasil tes dianalisis secara deskriptif kuantitatif untuk mengetahui seberapa besar peningkatan hasil belajar kognitif Bahasa Indonesia materi kalimat saran dengan media video pembelajaran. Data hasil tes yang diperoleh pada akhir siklus dihitung rata-rata kelasnya dan dihitung persentase siswa yang tuntas.

\section{HASIL DAN PEMBAHASAN}

Pada awalnya peneliti merenungkan hasil nilai siswa pada muatan pelajaran Bahasa Indonesia tentang kalimat saran menunjukan angka yang paling rendah dibandingkan dengan muatan mata pelajaran lainnya. Dari hasil penilaian sebelum melakukan tindakan pertama (siklus pertama), dikatahui kondisi awal prestasi belajar siswa. Hasil prestasi kondisi awal dapat dilihat dari data dibawah ini :

Tabel 1 Hasil belajar siswa pada kondisi awal Kondisi Awal

\begin{tabular}{ll}
\hline Keterangan & Kondisi awal \\
\hline Nilai tertinggi & 90 \\
\hline Nilai terendah & 20 \\
\hline Rata - rata Nilai & 57 \\
\hline Siswa belajar Tuntas & $40 \%$ \\
\hline Siswa belajar Belum Tuntas & $60 \%$ \\
\hline
\end{tabular}


Dari tabel di atas dapat dilihat bahwa nilai terendah yang diperoleh siswa adalah 20 , nilai tertinggi adalah 90 , dan rata-rata nilainya 57 , serta siswa yang telah belajar tuntas baru $40 \%$, maka masih banyak siswa yang belum mencapai nilai ketuntasan $(\mathrm{KKM}=70)$. Sehinga perlu diadakan tindakan untuk meningkatkan hasil belajar bahasa indonesia pada umumnya, dan pada materi kalimat saran pada khususnya.

Deskripsi Penelitian Siklus I

Data yang diperoleh pada tahap pratindakan dijadikan acuan dalam melaksanakan tindakan pada siklus pertama dengan tujuan agar diperoleh suatu peningkatan hasil belajar siswa. Pada penelitian ini setiap siklus terdiri dari empat komponen yaitu perencanaan, pelaksanaan tindakan, observasi, dan refleksi.

Perencanaan dilakukan dengan menyiapkan hal-hal yang dibutuhkan dalam melaksanakan tindakan pada proses pembelajaran Bahasa Indonesia tentang kalimat saran.

Pelaksanaan tindakan merupakan penerapan rancangan tindakan yang telah disusun berupa pembelajaran bahasa indonesia dengan menggunakan media video pembelajaran. Penelitian pada siklus I terdiri dari satu pertemuan.

Pengamatan atau Observasi dilaksanakan selama proses pembelajaran berlangsung dengan menggunakan lembar observasi yang telah dibuat sebelumnya.

Tabel 2. Hasil belajar siswa pada Siklus I

\begin{tabular}{lll}
\hline Keterangan & Hasil Belajar siklus I \\
\hline Nilai tertinggi & 100 \\
\hline Nilai terendah & 30 \\
\hline Rata - rata Nilai & 65 \\
\hline Siswa belajar Tuntas & $60 \%$ & \\
\hline Siswa belajar Belum Tuntas & $40 \%$ & Hasil Belajar siklus I \\
\hline \multicolumn{2}{c}{ Tabel 3. Perbandingan hasil tes kondisi awal dengan siklus I } \\
\hline Keterangan & Kondisi awal & 100 \\
\hline Nilai tertinggi & 90 & 30 \\
\hline Nilai terendah & 20 & 65 \\
\hline Rata - rata Nilai & 57 & $60 \%$ \\
\hline Siswa belajar Tuntas & $40 \%$ & $40 \%$ \\
\hline Siswa belajar & Belum & $60 \%$ \\
Tuntas & & \\
\hline
\end{tabular}

Dari hasil analisa data peningkatan hasil belajar kognitif siswa siklus I dapat disimpulkan bahwa persentasi hasil belajar siswa yang tuntas naik dari $40 \%$ kondisi awal menjadi $60 \%$ setelah siklus I, berarti mengalami kenaikan sebesar $20 \%$, dengan nilai batas tuntas $<70$. Adapun Nilai tertinggi pada kondisi awal adalah 90 setelah siklus I menjadi 100. Rata-rata nilai pada kondisi awal 57 setelah siklus I menjadi 65. Pada siklus I ternyata masih ada siswa yang belum tuntas belajarnya sehingga guru berusaha untuk mengadakan perbaikan bagi siswa yang belum mencapai batas tuntas, dan memberikan pengayaan kepada siswa yang sudah mencapai kriteria ketuntasan 


\section{SHEs: Conference Series $x(x)(20 x x) 00-00$}

minimal $(K K M=70)$. Pelaksanaan Perbaikan dan Pengayaan ini dilaksanakan pada siklus II.

Refleksi yang dilakukan pada akhir siklus I bertujuan untuk mengetahui keberhasilan dari pembelajaran yang telah dilakukan. Dalam hal ini peneliti dan mitra peneliti melakukan diskusi untuk mengkaji kembali atau mengevaluasi data dan tindakan yang telah dilakukan pada siklus I sebagai upaya perbaikan pada siklus selanjutnya. Berdasarkan hasil observasi dan hasil tes pada siklus I, indikator keberhasilan belum tercapai. Ada beberapa hal yang harus diperbaiki. Hal ini dimaksudkan untuk memperbaiki pelaksanaan pembelajaran bahasa indonesia materi kalimat saran dengan menggunakan media video pembelajaran agar dapat mencapai indikator keberhasilan yang telah ditentukan.

Pada penelitian ini setiap siklus terdiri dari empat komponen yaitu perencanaan, pelaksanaan tindakan, observasi, dan refleksi. Secara rinci sajian siklus 2 adalah sebagai berikut : a. Perencanaan, Perencanaan dilakukan dengan menyiapkan hal-hal yang dibutuhkan dalam melaksanakan tindakan pada proses pembelajaran Bahasa Indonesia, diantaranya: 1) Peneliti dan guru menetapkan waktu pelaksanaan tindakan kelas, 2) Membuat RPP yang didesain sesuai dengan penerapan penggunaan media dalam pembelajaran Bahasa Indonesia, 3) Menyiapkan media pembelajaran yang akan digunakan dalam penelitian, yaitu media video pembelajaran tentang kalimat saran, 4) Menyiapkan metode pembelajaran yang akan digunakan dalam penelitian, 5) Menyiapkan lembar observasi yang digunakan untuk mengamati aktivitas guru dan siswa selama proses pembelajaran, 6) Menyiapkan kamera untuk mendokumentasikan aktivitas guru dan siswa pada proses pembelajaran, 7) Menyiapkan evaluasi hasil belajar siswa yang digunakan pada akhir siklus. b. Pelaksanaan : Pelaksanaan tindakan merupakan penerapan rancangan tindakan yang telah disusun berupa pembelajaran bahasa indoneisa dengan menggunakan media video pembelajaran. Penelitian pada siklus II terdiri dari satu pertemuan. ( Kegiatan Awal, Kegiatan Inti dan Akhir ), c.Pengamatan : Observasi dilakukan oleh peneliti bekerjasama dengan mitra peneliti (teman sejawat). Teman sejawat yang bertindak mengamati aktivitas setiap siswa kelas III SD Negeri Luwunggede 04 selama proses pembelajaran, d. Refleksi : Dari hasil pelaksanaan perbaikan pembelajaran dan refleksi siklus II maka dapat disimpulkan bahwa pelaksanaan tindakan pembelajaran untuk meningkatkan hasil belajar siswa dalam kegiatan pembelajaran Bahasa Indonesia materi kalimat saran mengalami peningkatan pada siklus II

Tabel 4. Hasil belajar siswa pada Siklus II

\begin{tabular}{ll}
\hline Keterangan & Hasil Belajar siklus II \\
\hline Nilai tertinggi & 100 \\
\hline Nilai terendah & 60 \\
\hline Rata - rata Nilai & 83 \\
\hline Siswa belajar Tuntas & $90 \%$ \\
\hline Siswa belajar Belum Tuntas & $10 \%$ \\
\hline
\end{tabular}


Tabel 5. Perbandingan hasil tes kondisi awal dengan siklus I dan II

\begin{tabular}{|c|c|c|c|}
\hline Keterangan & Kondisi awal & Hasil Belajar & siklusHasil Belajar siklus II \\
\hline Nilai tertinggi & 90 & 100 & 100 \\
\hline Nilai terendah & 20 & 30 & 60 \\
\hline Rata - rata Nilai & 57 & 65 & 83 \\
\hline Siswa belajar Tuntas & $40 \%$ & $60 \%$ & $90 \%$ \\
\hline $\begin{array}{l}\text { Siswa belajar belum } \\
\text { s }\end{array}$ & $60 \%$ & $40 \%$ & $10 \%$ \\
\hline
\end{tabular}

Dari hasil analisa data peningkatan hasil belajar kognitif siswa siklus II dapat disimpulkan bahwa persentasi hasil belajar siswa yang tuntas naik dari $40 \%$ kondisi awal menjadi $90 \%$ setelah siklus 2, berarti mengalami kenaikan sebesar $50 \%$, dengan nilai batas tuntas < 70. Adapun nilai terendah pada siklus I adalah 30 sedangkan setelah siklus II mengalami kenaikan menjadi 60. Nilai tertinggi pada kondisi awal adalah 90 setelah siklus I menjadi 100, serta pada siklus II menjadi 100. Rata-rata nilai pada kondisi awal 57 setelah siklus I menjadi 65 dan pada siklus II menjadi 83. Hal itu menunjukkan bahwa hasil tindakan perbaikan pembelajaran pada tahap siklus II sudah ada peningkatan lebih besar dibandingkan dengan hasil pembelajaran pada siklus I, karena hampir semua siswa nilainya sudah memenuhi KKM, yaitu 70.

\section{SIMPULAN}

Berdasarkan hasil penelitian dan pembahasan pada bab sebelumnya, dapat disimpulkan bahwa penggunaan media video pembelajaran pada materi kalimat saran siswa kelas III semester 1 SD Negeri Luwunggede 04 Kecamatan Larangan Kabupatn Brebes Tahun Pelajaran 2020/2021 terbukti dapat meningkatkan hasil belajar siswa. Selanjutnya dapat disimpulkan bahwa media video pembelajaran dapat meningkatkan hasil belajar siswa dalam pembelajaran bahasa indonesia materi kalimat saran dengan hasil evaluasi pada kondisi awal rata-rata hanya 57, pada siklus 1 meningkat menjadi 65, pada siklus II meningkat lagi menjadi 83. Serta ketuntasan belajarnya juga mengalami peningkatan dari kondisi awal sebesar 40\%, siklus sebesar I 60\%, dan siklus II sebesar $90 \%$ siswa yang tuntas.

\section{DAFTAR PUSTAKA}

Arikunto, Suharsimi. (2006). Prosedur Penelitian. Jakarta: Rineka Cipta

Aqib, Zainal, dkk. (2011). Penelitian Tindakan Kelas untuk Guru SD, SLB, dan TK. Bandung: Yrama Widya.

Azhar Arsyad. (2004). Media Pembelajaran. Jakarta: PT. Raja Grafindo Persada.

Cheppy Riyana. (2007). Pedoman Pengembangan Media Video. Jakarta: P3AI UPI.

Isah Cahyani. (2013). Pembelajaran Bahasa Indonesia. Jakarta: Direktorat Jenderal Pendidikan Islam Departemen Agama Republik Indonesia

KBBI, A. (2012). Arti Kata Video. Diambil kembali dari KBBI Daring: http://kbbi.kemdikbud.go.id/entri/video

Purwanto, Ngalim. (1997). Psikologi Pendidikan. Bandung:Remaja Rosdkarya

Riyadi, Muchlisin (2019). Kajjian pustaka. Di akses dari https://www.kajianpustaka.com/2019/03/penelitian-tindakan-kelas-ptk.html

Slameto. (2003). Belajar dan Faktor-faktor yang mempengaruhinya. Jakarta: Rineka Cipta 